\title{
Brazilian university students in Spain: Motivations and decision factors
}

\author{
Luciano Kingeski(D), Jordi Olivella Nadal (D) \\ Polytechnic University of Catalonia - UPC (Spain) \\ luciano.kingeski@upc.edu,jorge.olivella@upc.edu
}

Received April, 2020

Accepted November, 2020

\begin{abstract}
Purpose: Our research objective is to carry out an analysis of the motivations and specific decision factors of Brazilian university students who will travel to Spain to continue their studies.

Design/methodology: The applied methodology has been to conduct online surveys among members of the Brazilian student community in Spain. For the design of the survey, we started with a previous exploratory study with in-depth individual interviews. The interviews were conducted based on a semistructured questionnaire inspired by the previous literature.
\end{abstract}

Findings: The comparison between the previous studies in the literature and the results of the survey shows that the factors "Academic level of the center" and "Prestige and prospects" of having studied abroad coincide with one another. Indeed, these factors are among the most significant in almost all of the studies and have also been highlighted by the respondents, confirming the importance of these factors in their decision to study abroad. On the other hand, the rest of the factors that appear to be the most relevant in the survey results are specific to and characterize the flow of students analyzed. Specifically, they concern the international experience, scholarships, image and culture of the country and the language.

Research limitations/implications: The sample is limited, due to the difficulty of contacting this type of subject, which made it necessary for the researchers to adopt various approach strategies.

Practical implications: The results obtained can benefit the recruitment of Brazilian students.

Social implications: Contributes to knowledge of the emigration flows and relations between the two countries.

Originality/value: The specific topic of Brazilian students in Spain has not been previously discussed.

Keywords: International mobility, International students, Higher education

Jel Codes: $\mathrm{I} 23$

\section{To cite this article:}

Kingeski, L. \& Olivella Nadal, J. (2020). Brazilian university students in Spain: Motivations and decision factors. Intangible Capital, 16(3), 91-106. https://doi.org/10.3926/ic.1651 


\section{Introduction and dimensions of the phenomenon}

Mobility in higher education is a phenomenon of increasing importance. The opportunity to obtain international experience is very important for students, as they will perform their professional activity in an extremely interrelated world. According to data from the OCDE (2019), between 1975 and 2017, the number of students traveling to countries other than their own to receive higher education increased from approximately 800,000 to more than 5 million. The primary destinations continue to be led by the same powers (USA and Europe, particularly the United Kingdom).

In the case of Spain, the presence of international students has also increased considerably in recent years. The flows of students to this country come from other European and Latin American countries, and to a lesser extent, from the rest of the world (Table 1).

\begin{tabular}{|l|r|r|}
\hline \multicolumn{1}{|c|}{ Origin } & 2016-2017 & 2000-2017 \\
\hline Latin America and the Caribbean & 30,057 & 289,262 \\
\hline North American and Western Europe & 23,067 & 248,527 \\
\hline Central and Eastern Europe & 3,968 & 49,811 \\
\hline Arab Countries & 2,743 & 48,819 \\
\hline Small Developing Countries & 45 & 17,901 \\
\hline East Asia and the Pacific & 2,899 & 16,460 \\
\hline Sub-Saharan Africa & 844 & 15,867 \\
\hline Southern and Western Asia & 1,099 & 5,813 \\
\hline Central Asia & 205 & 1,665 \\
\hline Total estimated number & $\mathbf{6 4 , 9 2 7}$ & $\mathbf{6 9 4 , 1 2 5}$ \\
\hline
\end{tabular}

Table 1. International students coming to Spain by continent of origin, 2000 to 2017 (UNESCO, 2019)

Among the Latin American countries sending students to Spain, the case of Brazil is worthy of special attention. Due to the linguistic factor, the presence of Brazilian students in Spain does not reach the levels of those from other Latin American countries. The scarce flow of immigration between Brazil and Spain is another factor to take into account when studying the flow of students in relation to other countries. In spite of this, both the flow of university students from Brazil to Spain and, in more general terms, the relations between Brazilian and Spanish universities are increasing in importance.

The topic of international academic mobility has received increasing interest in the literature in recent years. In spite of this, studies on the motivations of foreign students to come to Spain are still few. Specifically, the flow of students from Brazil to Spain has not previously been studied. This work intends to remediate this shortcoming.

This article is organized into five sections. The first section presents the topic and the dimension of the phenomenon. Section two presents the review of the literature, Section three describes the methodology and research objectives proposed for the study and Section four presents the results of the surveys. Finally, Section five presents the discussion and conclusions.

\subsection{International student mobility}

Different terms are used to characterize students who travel to other countries to study. The terms "foreign students" and "international students" are particularly common. UNESCO uses the term "international student mobility" to refer to this phenomenon (UNESCO, 2006). From this term comes the expression "internationally mobile students." UNESCO defines these students as those who have crossed a national border in order to study or who are registered in a distance learning program abroad. 
In this context, it is necessary to differentiate internationally mobile students from foreign students. Foreign students also include those who already lived in the country on a regular basis before beginning their studies, and who therefore have not traveled for this purpose. On the other hand, citizens living abroad could be considered to be international students, although generally speaking, this would be a fairly insignificant phenomenon. For this reason, the number of foreign students worldwide tends to be greater than the number of internationally mobile students (UNESCO, 2014).

In this article, for reasons of simplicity, we will refer to internationally mobile students as "international students."

International students as a whole can be classified into different groups, according to the reasons why they have decided to study abroad. Specifically, Marchetto (2005) establishes the following categories: those referred to as "freemovers", who finance their studies by means of their own resources; students who receive financial support of one type or another; refugee students; and students who emigrate for economic reasons.

Therefore, the international mobility of students is one of the most important methods of internationalization and one of its most visible dimensions. This acquires special significance in the context of an interdependent world economy, where knowledge is a key element of the workforce. This has led governments and institutions to promote and implement student mobility programs in order to expand their education and enrich their ways of thinking and working though contact with other cultures (Parra Sandoval, 2014).

Specifically in the case of Brazil, four stages are observed in the evolution of the Brazilian university exchanges abroad:

a) (...) the first inaugural period (between 1930 and 1950) is marked by the presence of visiting lecturers from Europe at newly established Brazilian universities; b) During the second reformist period (between 1960 and 1970), the programs emphasized the presence of consultants from the US and the granting of scholarships for master's and doctoral studies abroad; c) The third period of consolidation (between 1980 and 1990) emphasizes academic and marketing aspects, as internationalization seeks to expand and consolidate rigorous post-graduate programs in the country; d) The fourth period of diversification (from the year 2000 on) reflects the maturity of internationalization administered and financed by governmental agencies, and also the early steps towards internationalization administered by private enterprise (Lima \& Contel, 2011).

From a more general perspective, the international mobility of students forms part of a broader scope of cultural trends. The dissemination of a "youth culture of mobility is motivated less by the traditional economic factors of migration (income, employment, etc.) and more by factors related to education, leisure and the acquisition of experience" (Higher Education Funding Council for England, 2004).

Added to this is the fact that, according to Luchilo (2006), international student mobility as an instrument of cooperation is the most traditional approach, and is presided over by political-cultural considerations, the promotion of academic exchanges and development assistance. From this perspective, student mobility is considered a means of mutual knowledge between different countries and cultures.

\subsection{Spain as a receiving country and Brazil as an issuing country}

Globalization has helped diversify the countries that serve as destinations for international students. As previously presented, significant changes have occurred in the distribution around the world in recent years, and Spain has emerged as an option for Brazilian students in Europe for both graduate and post-graduate studies.

Among international university students in Spain, a total of 1,859 in 2009, 1,541 in 2012, 949 in 2014 and 1,402 in 2017 came from Brazil (OCDE Stats, 2019). The fluctuation in these figures very likely has to do with scholarship programs. Especially noteworthy is the program "Programa Ciência sem fronteiras (CsF)", created with the objective of promoting the consolidation, expansion and internationalization of Brazilian science and technology, innovation and competitiveness through international exchanges and mobility (Programa Ciência sem fronteiras, 2014). 
With regard to the destinations of Brazilian students abroad, between 2000 and 2017, Spain was the sixth most popular country option, receiving approximately 20,044 students, behind USA, Portugal, France, United Kingdom and Argentina. Considering only 2017 (the latest data available), Spain was the ninth most popular option. The primary destinations and the number of students in decreasing order are Argentina, with 12,789; USA, with 12,357; Portugal, with 7,764; Australia, with 5,551; France, with 4,171; Canada, with 2,979; Germany, with 2,575; United Kingdom, with 1,730; and finally, Spain, with 1,402, which is ahead of Italy, with 1,237 students (UNESCO, 2019).

In terms of internationalization policies, specifically in Spain, there is a growing interest in attracting international students. The Strategy for the Internationalization of Spanish Universities 2015-2020 by the Spanish Ministry of Education, Culture and Sports, emphasizes the importance of the international mobility of students and the government's interest in promoting it.

In this sense, Royal Decree 412/2014 eliminates the entrance exam requirement for foreigners in order to enter a degree program. In addition to promotion by the government, other important initiatives have been detected to attract foreign students in different autonomous communities. In some cases, changes are being promoted in regulations governing access and in the languages in which the instruction is provided in order to encourage their presence. Some centers are also focusing first and foremost on attention to foreign students (Olivella Nadal, 2016).

\section{Review of the literature}

The motivations for studying abroad can be distinguished according to different factors. On the individual level, for example, many consider that studying abroad helps a person more successfully meet the demands of the job market, and it also increases the international dimension in the workplace and boosts one's career in general (Teichler, 2007). In this same direction, studying at a top-quality institution, while financially taxing, increases the possibilities of getting a desirable job and provides better career prospects in today's world, characterized by economic, political, cultural, environmental and technological interdependence (Li \& Bray, 2007).

In order to determine the reasons for studying abroad, different authors have adopted what is known as the push-pull theory. This theory comes from the field of migration study and is considered an evolution of Ravenstein's theories, developed in England in the 19th century (Wang, 2010). This approach consists of considering those reasons that a person has for leaving a country as push factors, and those for specifically going to another as pull factors.

Altbach (1998) classifies the factors that lead students to study abroad from the perspective of the push-pull approach. In this area, the push factors are those situations in the country of origin that lead students to study in another country, and the pull factors are those characteristics of the destination country that motivate students to study there. Table 2 shows an example of push-pull factors corresponding to students from the so-called third world.

\begin{tabular}{|c|c|}
\hline Factors related to the country of origin - push & Factors related to the destination country - push \\
\hline 1. Availability of scholarships to study abroad. & 1. Availability of scholarships for international students. \\
\hline 2. Low-level educational institutions. & 2. Good-quality educational institutions. \\
\hline 3. Lack of research facilities. & 3. Availability of advanced research facilities. \\
\hline $\begin{array}{l}\text { 4. Lack of appropriate educational institutions or } \\
\text { difficulty in obtaining access to them. }\end{array}$ & $\begin{array}{l}\text { 4. Existence of appropriate educational institutions with } \\
\text { possibilities of being admitted. }\end{array}$ \\
\hline 5. Uncomfortable political situation. & 5. Comfortable political situation. \\
\hline 6. Greater appreciation of a foreign degree. & 6. Comfortable socioeconomic and political context. \\
\hline 7. Discrimination against minorities. & 7. Possibilities of having an international experience. \\
\hline
\end{tabular}

Table 2. Factors that have an influence on the decision to study abroad for students from the third world (Altbach, 1998) 
The push-pull model was originally developed to explain the factors that influence people to migrate to a certain country, but since then, it has been used by educational researchers to help explain the motivations and decisions of international students. Mazzarol and Soutar (2002) identify three stages as being the most common in the student's decision-making process: the decision to study abroad, the choice of country to travel to and the choice of university. The first stage corresponds to the push factors, while the second and third stages constitute the attraction to the destination or pull factors.

There are different advantages for students who travel abroad to complete their studies, ranging from learning a language, contacts with other cultures and a new perspective on their own country to expanding their résumé. The result is that every day new students strive to study in a foreign country. In the review of the literature, it is possible to find some studies that were conducted in order to understand the benefits and impacts of an experience abroad. For a better understanding, this section is divided into three types of studies:

Table 3 shows those studies that have as a destination those countries with the greatest tradition in terms of international academic mobility, with the main motivations identified by the students who choose these countries. Next, Table 4 is dedicated to those studies on countries that are beginning to capture attention in higher education as the new destinations for studying abroad. These are the cases of Asia and the Middle East. In particular, in the case of China, the authors predict that it will very soon take over from the United Kingdom as the second-place destination. Finally, Table 5 presents those studies that are related to Brazil and Spain. It should particularly be noted that these studies are very limited, and there are few cases in the literature. The studies identified are broader in their analysis and do not deal exclusively with the motivations of Brazilian students.

\begin{tabular}{|c|c|c|}
\hline Authors & $\begin{array}{c}\text { Countries of origin } \\
\text { and destination }\end{array}$ & Decision factors \\
\hline $\begin{array}{l}\text { Mazzarol \& } \\
\text { Soutar }(2002)\end{array}$ & Various to Australia. & $\begin{array}{l}\text { Recommendations from the environment, cost, image and culture of the } \\
\text { country, academic level of the center, prestige and prospects, safety. }\end{array}$ \\
\hline $\begin{array}{l}\text { Binsardi \& } \\
\text { Ekwulugo (2003) }\end{array}$ & $\begin{array}{l}\text { Various to the } \\
\text { United Kingdom. }\end{array}$ & $\begin{array}{l}\text { Housing, cost, image and culture of the country, academic level of the center, } \\
\text { academic level of the country, prestige and prospects, selection process, safety. }\end{array}$ \\
\hline Pimpa (2005) & $\begin{array}{l}\text { Thailand to } \\
\text { Australia. }\end{array}$ & Academic level of the center, prestige and prospects. \\
\hline $\begin{array}{l}\text { Shanka, Quintal \& } \\
\text { Taylor (2005) }\end{array}$ & Various to Aust & $\begin{array}{l}\text { Recommendations from the environment, cost, geographical distance, } \\
\text { academic level of the center, safety. }\end{array}$ \\
\hline $\begin{array}{l}\text { Gatfield \& Chen } \\
\text { (2006) }\end{array}$ & Taiwan to Various. & $\begin{array}{l}\text { Recommendations from the environment, cost, academic level of the center, } \\
\text { prestige and prospects. }\end{array}$ \\
\hline $\begin{array}{l}\text { Maringe \& } \\
\text { Carter(2007) }\end{array}$ & $\begin{array}{l}\text { Africa to the United } \\
\text { Kingdom. }\end{array}$ & Academic level of the center, prestige and prospects, selection process. \\
\hline Yang (2007) & China to Australia. & $\begin{array}{l}\text { Cost, lack of positions, image and culture of the country, interest in emigrating, } \\
\text { academic level of the country, selection process. }\end{array}$ \\
\hline Chen (2008) & Various to Canada. & $\begin{array}{l}\text { Image and culture of the country, academic level of the center, prestige and } \\
\text { prospects, safety, visa. }\end{array}$ \\
\hline $\begin{array}{l}\text { Abubakar, Shanka } \\
\text { \& Muuka (2010) }\end{array}$ & Various to Australia. & $\begin{array}{l}\text { Recommendations from the environment, cost, geographical distance, } \\
\text { academic level of the center, safety. }\end{array}$ \\
\hline $\begin{array}{l}\text { Wilkins } \\
\text { Balakrishnan \& } \\
\text { Huisman (2011) }\end{array}$ & $\begin{array}{l}\text { Various to the } \\
\text { United Kingdom. }\end{array}$ & $\begin{array}{l}\text { Language, image and culture of the country, academic level of the center, } \\
\text { prestige and prospects. }\end{array}$ \\
\hline $\begin{array}{l}\text { Mukherjee \& } \\
\text { Chanda (2012) }\end{array}$ & India to Europe. & $\begin{array}{l}\text { Scholarships, language, interest in emigrating, academic level of the center, } \\
\text { academic level of the country, prestige and prospects, selection process. }\end{array}$ \\
\hline $\begin{array}{l}\text { James-Maceachern } \\
\& \text { Yun (2017) }\end{array}$ & Various to Canada. & Cost, language, academic level of the center, safety. \\
\hline
\end{tabular}

Table 3. Decision factors for traditional destinations 


\begin{tabular}{|c|c|c|}
\hline Authors & $\begin{array}{l}\text { Countries of origin } \\
\text { and destination }\end{array}$ & Decision factors \\
\hline $\begin{array}{l}\text { Joseph \& Joseph } \\
(2000)\end{array}$ & $\begin{array}{l}\text { Indonesia to } \\
\text { various. }\end{array}$ & Cost, academic level of the center, prestige and prospects, safety. \\
\hline $\begin{array}{l}\text { Li \& Bray } \\
(2007)\end{array}$ & $\begin{array}{l}\text { China to Hong } \\
\text { Kong, Macao. }\end{array}$ & $\begin{array}{l}\text { International experience, image and culture of the country, academic level of } \\
\text { the center, prestige and prospects. }\end{array}$ \\
\hline $\begin{array}{l}\text { Padlee, } \\
\text { Kamaruddin \& } \\
\text { Baharun (2010) }\end{array}$ & $\begin{array}{l}\text { Various to } \\
\text { Malaysia. }\end{array}$ & $\begin{array}{l}\text { Scholarships, recommendations from the environment, cost, language, } \\
\text { academic level of the center, prestige and prospects. }\end{array}$ \\
\hline $\begin{array}{l}\text { Jianvittayakit \& } \\
\text { Dimanche (2010) }\end{array}$ & $\begin{array}{l}\text { Various to } \\
\text { Thailand. }\end{array}$ & $\begin{array}{l}\text { Cost, image and culture of the country, academic level of the country, prestige } \\
\text { and prospects. }\end{array}$ \\
\hline $\begin{array}{l}\text { Cao, Zhu \& } \\
\text { Meng (2016) }\end{array}$ & Various to China. & $\begin{array}{l}\text { Scholarships, cost, language, image and culture of the country, academic level } \\
\text { of the center, prestige and prospects. }\end{array}$ \\
\hline $\begin{array}{l}\text { Ahmad, Hassan, } \\
\text { Al-Ahmedi (2017) }\end{array}$ & $\begin{array}{l}\text { Iraqi Kurdistan to } \\
\text { various. }\end{array}$ & $\begin{array}{l}\text { International experience, language, academic level of the center, prestige and } \\
\text { prospects. }\end{array}$ \\
\hline $\begin{array}{l}\text { Ahmad \& } \\
\text { Hussain (2017) }\end{array}$ & $\begin{array}{l}\text { Africa to United } \\
\text { Arab Emirates. }\end{array}$ & Economy of the country, image and culture of the country, safety. \\
\hline $\begin{array}{l}\text { Ahmad \& Shah } \\
(2018)\end{array}$ & Various to China. & $\begin{array}{l}\text { Scholarships, cost, international experience, language, academic level of the } \\
\text { center, academic level of the country. }\end{array}$ \\
\hline
\end{tabular}

Table 4. Decision factors for new destinations

\begin{tabular}{|l|l|l|}
\hline \multicolumn{1}{|c|}{ Authors } & $\begin{array}{l}\text { Countries of origin } \\
\text { and destination }\end{array}$ & \multicolumn{1}{c|}{ Decision factors } \\
\hline Foster (2014) & $\begin{array}{l}\text { Brazil to the } \\
\text { United Kingdom. }\end{array}$ & $\begin{array}{l}\text { International experience, language, academic level of the center, prestige and } \\
\text { prospects. }\end{array}$ \\
\hline $\begin{array}{l}\text { Oliveira \& } \\
\text { Freitas (2016) }\end{array}$ & $\begin{array}{l}\text { Brazil and others to } \\
\text { various. }\end{array}$ & $\begin{array}{l}\text { Recommendations from the environment, international experience, language, } \\
\text { image and culture of the country, academic level of the center, academic level } \\
\text { of the country, prestige and prospects. }\end{array}$ \\
\hline $\begin{array}{l}\text { Iorio \& Lucinda } \\
(2018)\end{array}$ & Brazil to Portugal. & $\begin{array}{l}\text { Cost, international experience, language, image and culture of the country, } \\
\text { academic level of the center, prestige and prospects, safety. }\end{array}$ \\
\hline $\begin{array}{l}\text { Trejo Peña \& } \\
\text { Bequir (2018) }\end{array}$ & Mexico to Spain. & $\begin{array}{l}\text { Cost, geographical distance, language, academic level of the center, prestige } \\
\text { and prospects. }\end{array}$ \\
\hline
\end{tabular}

Table 5. Decision factors with origin in Brazil or destination in Spain

Since there are so few studies in the literature related to Brazil and Spain, it is believed to be necessary to describe certain particularities of these cases. The study by Foster (2014), in addition to presenting the decision factors for studying in the United Kingdom, also presents the main barriers for Brazilian students who intend to study in this country. In decreasing order, mentioned are the cost of mobility, the distance from the country of origin, the difficulty in obtaining a scholarship for studying, difficulties with the language, the climate of the country, and finally, the food. However, the study by Oliveira and Freitas (2016), in addition to analyzing the motivations for Brazilian and international students, also analyzes the motivations of the professors, a category that was not taken into consideration for this specific study.

In the study by Iorio and Lucinda (2018), it is possible to verify many similarities between Portugal and Spain in the choice by Brazilian students who decide to study abroad. Among the factors analyzed by the authors, international experience, future prospects, the academic level of the centers, the importance of the language, the culture and the cost were also considered as important and critical for students traveling to Spain. Finally, Trejo Peña and Bequir (2018) report a very important motivating factor for international mobility by Mexican students who choose Spain for their higher education, referring to the dissatisfaction with the work environment 
experienced in their country of origin by Mexican students, associated with precarious jobs and low salaries, a factor that is not as evident in other studies.

As could be expected, the country or countries of origin and the destination country or countries determine to a large extent which factors are the most relevant. For this reason, specific studies are required on the different flows, and in particular, the flow of Brazilian students to Spain, which is analyzed in the present work.

\section{Methodology}

Our research objective is to analyze the specific motivations and decision factors of Brazilian university students who will travel to Spain to further their education. The methodology applied consisted of developing online surveys among the community of Brazilian students in Spain.

\section{- Survey questionnaire}

The survey design was based on a previous exploratory study in which the factors to be considered were identified (Kingeski \& Olivella Nadal, 2018). The authors opted for qualitative information gathering techniques in the first stage of this work, with individual in-depth interviews with 28 Brazilian students in Spain. The interviews were carried out using a semi-structured questionnaire based on the previous literature. Based on the results of this study, a questionnaire was prepared, which is presented in Table 6. Among the factors to keep in mind are those most commonly appearing in the literature as a whole, which have also been considered in the analysis of the literature that was carried out in Section 2. The questionnaire distinguishes whether Spain was the first option for studying abroad, the motivations for studying abroad in general and the intrinsic motivations to travel to Spain. In the last two blocks, a list of possible factors was considered, and the interviewees were asked whether each of the factors had been taken into account, had been a critical factor or had had no influence on their decision to study in Spain.

\begin{tabular}{|c|c|c|}
\hline Subject & Questions & Yes/No \\
\hline $\begin{array}{l}\text { First country } \\
\text { option }\end{array}$ & Spain was my first option of country to study abroad. & \multirow{3}{*}{$\begin{array}{l}\text { They did not } \\
\text { consider it./They } \\
\text { considered it./It } \\
\text { was a critical factor. }\end{array}$} \\
\hline $\begin{array}{l}\text { Motivations for } \\
\text { studying abroad }\end{array}$ & $\begin{array}{l}\text { International experience, prestige and future prospects, interest in emigrating, } \\
\text { availability of scholarships, lack of positions in Brazil. }\end{array}$ & \\
\hline $\begin{array}{l}\text { Motivations in the } \\
\text { choice of Spain }\end{array}$ & $\begin{array}{l}\text { Cost of mobility, study visa, culture of Spain, language, scholarships to study } \\
\text { in Spain, academic level of the country, academic level of the center, position } \\
\text { in the rankings, economy of Spain, previous experience, advice from family } \\
\text { and friends. }\end{array}$ & \\
\hline
\end{tabular}

Table 6. Survey

\section{- Sampling and survey administration}

225 students were surveyed who were registered in doctoral, official master's, undergraduate degree and postgraduate programs in Spain. Given that the number of post-graduate students was ultimately only nine, they were excluded from the sample for being insignificant. The survey was administered between January and March 2019.

The survey was administered for the first time to a pilot group of 10 students, and then it was adjusted according to the results obtained from these preliminary tests and finally replicated with the Brazilian students. In order to obtain the largest number of responses, the sampling technique known as snowball sampling was used. This technique is generally selected to provide methods of contact with populations or groups characterized as being difficult to access, which is very common in this type of research. The sample obtained for this study is defined as non-probability, as it is relatively homogeneous. It is believed that with this number of responses, a level of saturation is reached in order to achieve the results proposed at the start of the study. 
To gain access to the survey respondents, a link was sent by email to Brazilian students, accessed by the following means: the database belonging to the National Council of Scientific and Technological Development (CNPq) and the Programa Ciência sem fronteiras (CsF), a résumé bank of researchers registered on the Lattes/CNPq platform, individual contacts, Brazilian communities in Spain, Facebook, LinkedIn, the Brazilian Embassy in Madrid, the Association of Brazilian Researchers in Catalonia (APEC), the University of Salamanca - Center for Brazilian Studies (CEB) and the University of Valladolid - Tordesillas Center for Relations with Ibero-America and indications from other students. In all cases, the confidentiality of the evaluations and comments provided by the survey respondents was ensured.

\section{Survey results}

\subsection{Sociodemographic data of the survey respondents}

Table 7 below presents the sample size, the study program in Spain and gender. These data merely report the condition of the survey respondents in this study, but they are not to be considered an indicator of trends among the population of Brazilian students who travel to Spain.

\begin{tabular}{|l|r|r|r|}
\hline $\begin{array}{c}\text { Program of study } \\
\text { in Spain }\end{array}$ & Female & Male & Total \\
\hline Doctorate & 72 & 47 & 119 \\
\hline Master's & 25 & 9 & 34 \\
\hline Undergraduate Degree & 42 & 21 & 63 \\
\hline Total & $\mathbf{1 3 9}$ & $\mathbf{7 7}$ & $\mathbf{2 1 6}$ \\
\hline
\end{tabular}

Table 7. Sample size and gender

In this sample, a larger number of students obtaining an educational qualification in Spain was identified (approximately 56.94\%). Table 8 below shows the distribution of students according to the programs in which they were enrolled in Spain, in relation to the place where the educational qualification is earned.

\begin{tabular}{|l|r|r|r|r|}
\hline \multicolumn{1}{|c|}{$\begin{array}{c}\text { Program of study } \\
\text { in Spain }\end{array}$} & \multicolumn{1}{c|}{ Brazil } & \multicolumn{1}{c|}{ Spain } & \multicolumn{1}{c|}{ Both } & \multicolumn{1}{c|}{ Total } \\
\hline Doctorate & 21 & 84 & 14 & 119 \\
\hline Master's & 1 & 31 & 2 & 34 \\
\hline Undergraduate Degree & 50 & 8 & 5 & 63 \\
\hline Total & $\mathbf{7 2}$ & $\mathbf{1 2 3}$ & $\mathbf{2 1}$ & $\mathbf{2 1 6}$ \\
\hline
\end{tabular}

Table 8. Place where the educational qualification is obtained

With regard to the age of the students, a wide distribution was shown, with students as young as eighteen years of age, with little academic or professional experience and strong family ties, and up to students over 50 years of age, who traveled to Spain to pursue their studies. It can thus be inferred that studying in Spain for many of those surveyed is an experience that takes place following a stage of professional activity.

With regard to the place of origin of the students, of the 26 states in Brazil, responses were obtained from 21 of them, which represents approximately $77.78 \%$ of the total. The main five states in descending order of number of students were São Paulo, Minas Gerais, Rio Grande do Sul, Paraná and Río de Janeiro. As far as the cities are concerned, students were originally from 112 different cities.

In terms of the autonomous communities at the destination, of the 17 communities in Spain, responses were received from students in 15 of them. The autonomous communities of the Canary Islands and Navarre were the only ones not selected as a destination. It can be said that the destination flow of the Brazilian students to 
Spain is not limited to a specific area, but there are certain concentrations of interest. Finally, with regard to the destination cities, wide ranging results were also obtained, with responses from 39 different cities. The main cities in decreasing order chosen by students were Madrid, Barcelona, Salamanca, Valencia, Jaén, Seville, Valladolid, Granada, Alicante and León (Table 9).

\begin{tabular}{|l|r|r|r|r|}
\hline $\begin{array}{c}\text { Autonomous communities } \\
\text { of destination }\end{array}$ & Doctorate & \multicolumn{1}{|c|}{ Master's } & Undergraduate Degree & \multicolumn{1}{c|}{ Total } \\
\hline Madrid & 29 & 3 & 31 & 63 \\
\hline Catalonia & 25 & 6 & 6 & 37 \\
\hline Andalusia & 15 & 8 & 9 & 32 \\
\hline Castile and León & 18 & 6 & 6 & 30 \\
\hline Valencia & 15 & 5 & 3 & 23 \\
\hline Other communities & 17 & 6 & 8 & 31 \\
\hline Total & $\mathbf{1 1 9}$ & $\mathbf{3 4}$ & $\mathbf{6 3}$ & $\mathbf{2 1 6}$ \\
\hline
\end{tabular}

Table 9. Autonomous communities of destination by student group

With regard to the center of studies, a total of 63 were present in the sample. The ten universities most sought after by Brazilian students in decreasing order were the Universidad Autónoma de Madrid (38), Universidad de Salamanca (24), Universidad de Barcelona (10), Universidad de Jaén (10), Universidad de Sevilla (9), Universidad Politécnica de Cataluña (9), Universidad Autónoma de Barcelona (8), Universidad Politécnica de Valencia (7), Universidad de Valladolid (6) and Universidad de Valencia (5).

The social sciences and human sciences were the areas of knowledge with the greatest representation of doctoral and master's degree students. Meanwhile, undergraduate students were represented in the areas of engineering, architecture and related fields and mathematics and natural sciences (Table 10).

\begin{tabular}{|l|r|r|r|r|}
\hline \multicolumn{1}{|c|}{ Area of knowledge } & Doctorate & Master's & Undergraduate Degree & \multicolumn{1}{c|}{ Total } \\
\hline Mathematics and Natural Sciences & 23 & 1 & 15 & 39 \\
\hline Engineering, Architecture and similar disciplines & 18 & 3 & 40 \\
\hline Mathematics and Natural Sciences & 23 & 1 & 19 & 39 \\
\hline Health Sciences & 19 & 0 & 71 & 30 \\
\hline Economics, Administration and similar disciplines & 5 & 7 & 4 & 16 \\
\hline Agronomy, Veterinary Science and similar disciplines & 10 & 2 & 2 & 14 \\
\hline Education Sciences & 5 & 2 & 2 & 9 \\
\hline Fine Arts & $\mathbf{1 1 9}$ & $\mathbf{3 4}$ & 1 & 7 \\
\hline Total & 3 & $\mathbf{6 3}$ & $\mathbf{2 1 6}$ \\
\hline
\end{tabular}

Table 10. Areas of knowledge of Brazilian students

Table 11 below shows the distribution of scholarships according to the programs of study in Spain.

\begin{tabular}{|l|r|r|r|r|r|}
\hline Programs in Spain & \multicolumn{1}{|c|}{$\begin{array}{c}\text { With } \\
\text { scholarships }\end{array}$} & \multicolumn{1}{c|}{$\begin{array}{c}\text { Without } \\
\text { scholarships }\end{array}$} & \multicolumn{1}{c|}{ Total } \\
\hline Doctorate & 97 & $81.51 \%$ & 22 & $18.49 \%$ & 119 \\
\hline Master's & 20 & $58.82 \%$ & 14 & $41.18 \%$ & 34 \\
\hline Undergraduate Degree & 54 & $85.71 \%$ & 9 & $14.29 \%$ & 63 \\
\hline Total & $\mathbf{1 7 1}$ & $\mathbf{7 9 . 1 6 \%}$ & $\mathbf{4 5}$ & $\mathbf{2 0 . 8 4 \%}$ & $\mathbf{2 1 6}$ \\
\hline
\end{tabular}

Table 11. Distribution of the scholarships 
When studying the time Brazilian students spend in Spain, it is possible to observe that longer stays correspond largely to research purposes, primarily in full doctoral programs and with few exceptions, students who complete entire undergraduate degrees in Spain. In this sample, only four cases were identified (Table 12).

\begin{tabular}{|l|r|r|r|r|}
\hline Period of studies & Doctorate & \multicolumn{1}{|c|}{ Master's } & Undergraduate Degree & \multicolumn{1}{c|}{ Total } \\
\hline Less than 1 year & 9 & 1 & 15 & 25 \\
\hline 1 year & 16 & 21 & 43 & 80 \\
\hline 2 years & 10 & 10 & 0 & 20 \\
\hline 3 years & 19 & 1 & 1 & 21 \\
\hline 4 years & 39 & 0 & 4 & 43 \\
\hline 5 years or more & 26 & 1 & 0 & 27 \\
\hline Total & $\mathbf{1 1 9}$ & $\mathbf{3 4}$ & $\mathbf{6 3}$ & $\mathbf{2 1 6}$ \\
\hline
\end{tabular}

Table 12. Study time in Spain

\subsection{Motivations for studying abroad}

This block analyzed five factors: the international experience, prestige and prospects, interest in emigrating, availability of scholarships and the lack of positions in programs in Brazil. Figure 1 below presents the overall results and Table 13 shows the results by groups of students by program in Spain.

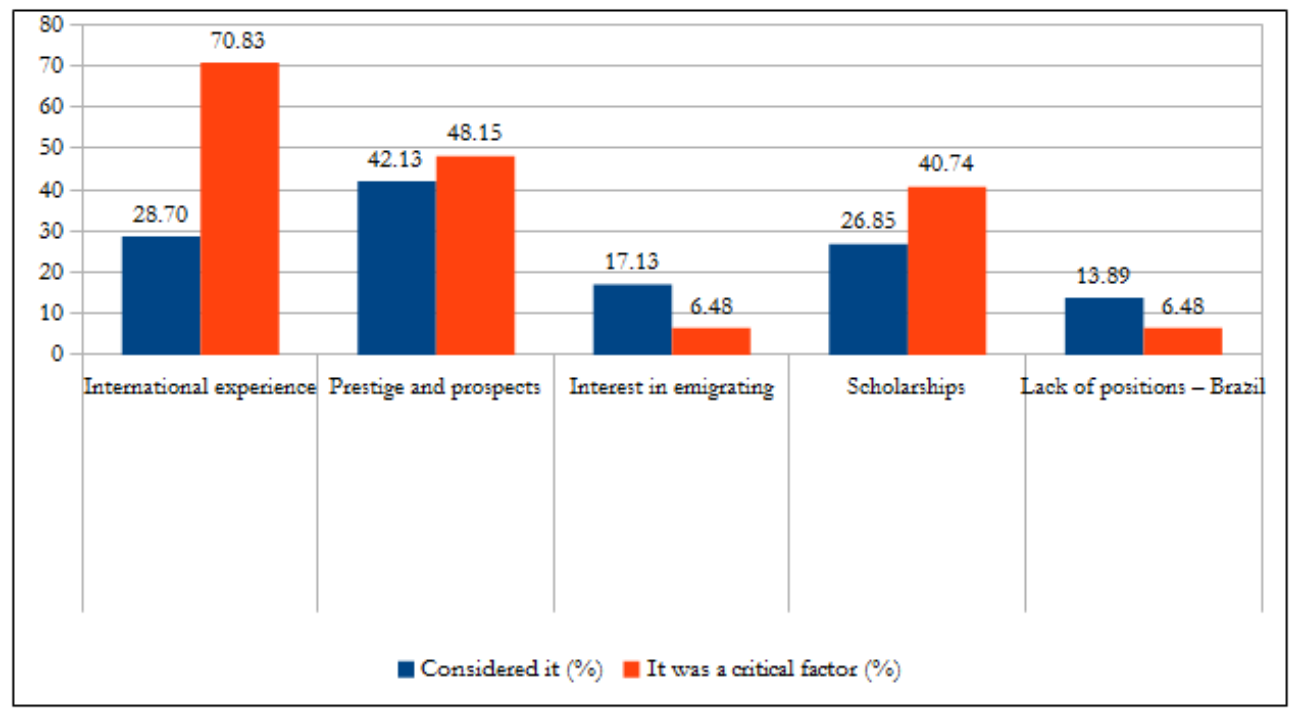

Figure 1. Motivations for studying abroad - overall results

\begin{tabular}{|c|c|c|c|c|c|c|}
\hline \multirow{2}{*}{ Decision factors } & \multicolumn{2}{|c|}{ Doctorate } & \multicolumn{2}{|c|}{ Master's } & \multicolumn{2}{|c|}{ Undergraduate Degree } \\
\hline & Con & $\mathrm{CF}$ & Con & $\mathrm{CF}$ & Con & $\mathrm{CF}$ \\
\hline International experience & $33.61 \%$ & $65.55 \%$ & $32.35 \%$ & $67.65 \%$ & $17.46 \%$ & $82.54 \%$ \\
\hline Prestige and prospects & $44.54 \%$ & $42.02 \%$ & $44.12 \%$ & $52.94 \%$ & $36.51 \%$ & $57.14 \%$ \\
\hline Interest in emigrating & $12.61 \%$ & $4.20 \%$ & $26.47 \%$ & $2.94 \%$ & $20.63 \%$ & $12.70 \%$ \\
\hline Scholarships & $24.37 \%$ & $31.93 \%$ & $26.47 \%$ & $38.24 \%$ & $31.75 \%$ & $58.73 \%$ \\
\hline Lack of positions & $14.29 \%$ & $9.24 \%$ & $32.35 \%$ & $5.88 \%$ & $3.17 \%$ & $1.59 \%$ \\
\hline
\end{tabular}

Legend: Con: Considered it; CF: It was a critical factor.

Table 13. Motivations to study abroad by groups of students 
In this analysis, the international experience abroad and the prestige and future prospects were the most important factors chosen above the rest. As we have seen, the availability of scholarships was a determining factor for a large share of the students when pursuing their studies, with $79.16 \%$ of the students using this resource. It should be pointed out that Spain lacks a vast program of incentives in the form of scholarships for international students.

The interest of students in emigrating to Spain once they finish their studies proves to be a factor that is not very important; this may be explained by the fact that most of the scholarship aid is granted by Brazilian programs, which require them to return to Brazil.

The lack of positions in Brazilian universities, especially in post-graduate programs, does not appear as a problem in this sample, with greater representativeness in this case shown by master's degree students. Meanwhile, the results identified in the previous stage (qualitative) in relation to this factor reveal that 22 of the 28 students expressed difficulties in accessing post-graduate programs in Brazil due to the lack of positions.

\subsection{Motivations in the choice of Spain}

In this section, we began by attempting to identify the real interest and professional focus of Brazilian students who moved to Spain. Of them, $62.50 \%$ chose Spain as their first option for studying abroad, while $37.50 \%$ wanted to go to other countries, but for various reasons ended up in Spain. The United Kingdom and the USA were the main destinations sought by the students, followed by Germany, Portugal and Italy.

Below five decision factors are analyzed with regard to the difficulty to access higher education in Spain. They are: scholarships to study in Spain, the Spanish language, the culture, the study visa and the cost of the mobility. Figure 2 below presents the overall results and Table 14 shows the results by groups of students.

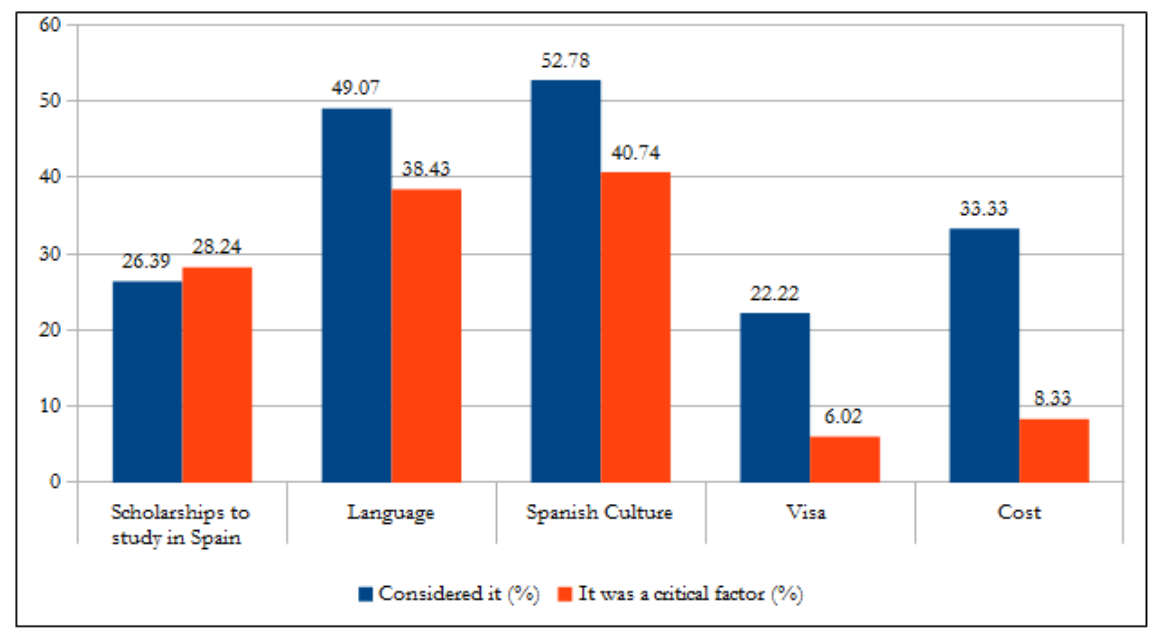

Figure 2. Factors related to the difficulty to access higher education - overall results

\begin{tabular}{|l|r|r|r|r|r|r|}
\hline \multirow{2}{*}{ Decision factors } & \multicolumn{2}{|c|}{ Doctorate } & \multicolumn{2}{c|}{ Master's } & \multicolumn{2}{c|}{ Undergraduate Degree } \\
\cline { 2 - 7 } & \multicolumn{1}{|c|}{ Con } & \multicolumn{1}{c|}{ CF } & \multicolumn{1}{c|}{ Con } & \multicolumn{1}{c|}{ CF } & \multicolumn{1}{c|}{ Con } & \multicolumn{1}{c|}{ CF } \\
\hline Scholarships to study in Spain & $18.49 \%$ & $21.01 \%$ & $23.53 \%$ & $29.41 \%$ & $42.86 \%$ & $41.27 \%$ \\
\hline Language & $52.10 \%$ & $28.57 \%$ & $50 \%$ & $41.18 \%$ & $42.86 \%$ & $55.56 \%$ \\
\hline Spanish Culture & $56.30 \%$ & $36.13 \%$ & $47.06 \%$ & $44.12 \%$ & $49.21 \%$ & $47.62 \%$ \\
\hline Visa & $23.53 \%$ & $5.04 \%$ & $17.65 \%$ & $8.82 \%$ & $22.22 \%$ & $6.35 \%$ \\
\hline Cost & $36.13 \%$ & $7.56 \%$ & $35.29 \%$ & $8.82 \%$ & $26.98 \%$ & $9.52 \%$ \\
\hline
\end{tabular}

Legend: Con: Considered it; CF: It was a critical factor.

Table 14. Factors related to the difficulty in accessing higher education 
For many Brazilian students, the Spanish language represents a more accessible option for studying than a country where English prevails, for example. In all student groups, more than $50 \%$ stated that this was an important or critical factor.

The general culture in Spain is a factor that Brazilian students took into consideration in many cases. This shows that in the mobility process abroad, many students seek similarities with their country of origin so that adaptation is as natural as possible. With regard to obtaining a Spanish student visa, this does not tend to be a problem, unlike in other countries where this factor is often a problem. In all student groups, more than $70 \%$ stated that this factor was not important. With regard to the costs, it can be stated that in Spain they are lower than in countries like the USA and the United Kingdom, which are the main destinations for international students around the world. All groups expressed concern with this factor.

The six decision factors are analyzed below, with regard to the attraction to the destination country, the academic level in Spain, the academic level of the center, the position in the rankings, the Spanish economy, previous experience abroad and the influence from the student's environment (family and friends). Figure 3 below presents the overall results and Table 15 shows the results by groups of students.

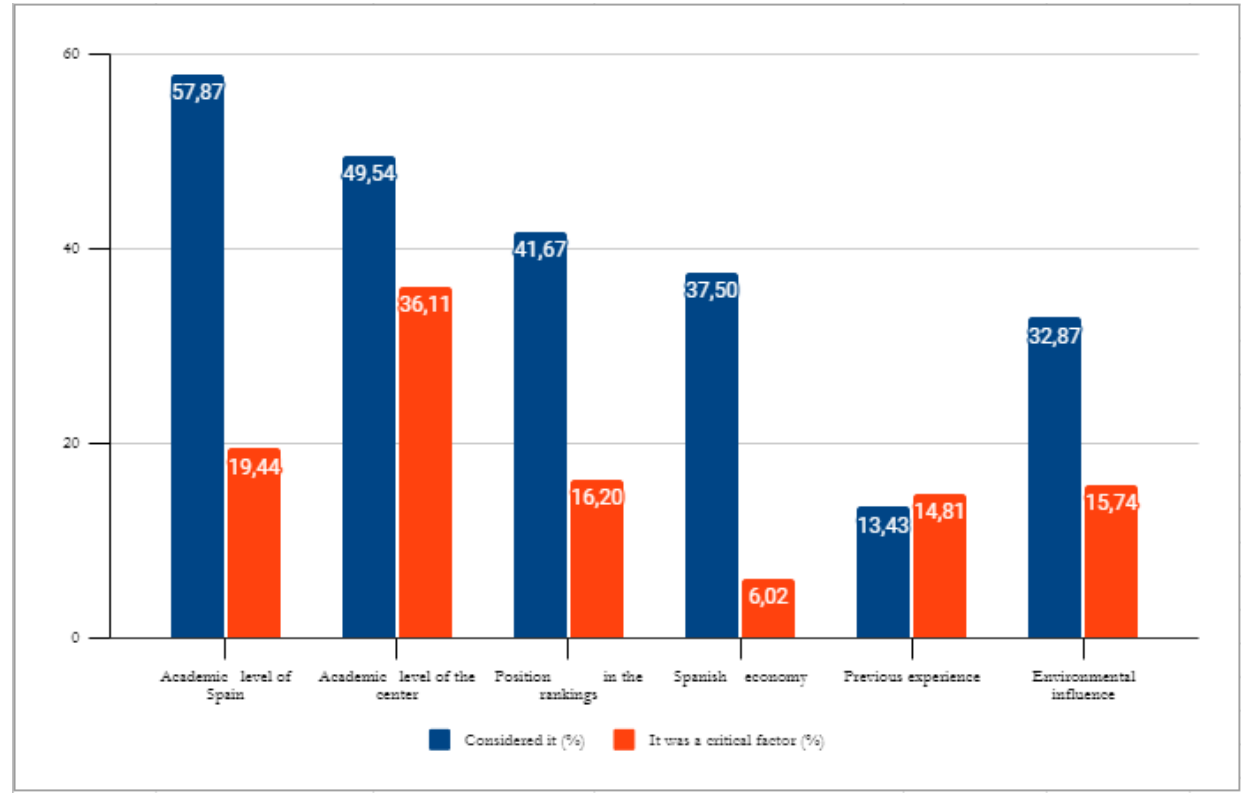

Figure 3. Factors of attraction to the destination - overall results

\begin{tabular}{|l|c|r|r|r|r|r|}
\hline \multirow{2}{*}{ Decision factors } & \multicolumn{2}{|c|}{ Doctorate } & \multicolumn{2}{c|}{ Master's } & \multicolumn{2}{c|}{ Undergraduate Degree } \\
\cline { 2 - 7 } & Con & CF & Con & \multicolumn{1}{c|}{ CF } & \multicolumn{1}{c|}{ Con } & CF \\
\hline Academic level of Spain & $53.78 \%$ & $24.37 \%$ & $61.76 \%$ & $14.71 \%$ & $63.49 \%$ & $12.70 \%$ \\
\hline Academic level of the center & $47.06 \%$ & $39.50 \%$ & $58.82 \%$ & $23.53 \%$ & $49.21 \%$ & $36.51 \%$ \\
\hline Position in the rankings & $37.82 \%$ & $19.33 \%$ & $44.12 \%$ & $5.88 \%$ & $47.62 \%$ & $15.87 \%$ \\
\hline Spanish economy & $34.45 \%$ & $8.40 \%$ & $38.24 \%$ & $5.88 \%$ & $42.86 \%$ & $1.59 \%$ \\
\hline Previous experience & $13.45 \%$ & $14.29 \%$ & $23.53 \%$ & $23.53 \%$ & $7.94 \%$ & $11.11 \%$ \\
\hline Environmental influence & $31.93 \%$ & $17.65 \%$ & $44.12 \%$ & $5.88 \%$ & $28.57 \%$ & $17.46 \%$ \\
\hline
\end{tabular}

Legend: Con: Considered it; CF: It was a critical factor.

Table 15. Factors of attraction to the destination

The academic level of the center was the most important factor in this block of factors, followed by the academic level of Spain. The position in the rankings, the Spanish economy, previous experience abroad and the 
influence from the environment appeared to be much less important than the two previous factors. Few cases of students were identified in this sample who had previous experience in exchange programs or short stays before starting their higher education in Spain.

\section{Discussion and conclusions}

To compare these results with the previous literature, the results of the previous literature have been summarized as shown in Table 16. The table represents the factors that have been taken into consideration in the review of the literature and on the survey. The data shown are the number the different types of works that considered each factor to be important. As can be seen, the results of previous studies are quite diverse, and thus we cannot claim a confirmation of clearly established results, rather the agreement (or lack thereof) with the general lines of the previous results. Finally, the survey results are indicated for each factor.

\begin{tabular}{|c|c|c|c|c|c|}
\hline Decision factors & $\begin{array}{l}\text { Traditional } \\
\text { Destinations }\end{array}$ & $\begin{array}{c}\text { New } \\
\text { Destinations }\end{array}$ & $\begin{array}{c}\text { Origin in } \\
\text { Brazil }\end{array}$ & $\begin{array}{l}\text { Destination } \\
\text { Spain }\end{array}$ & Survey result $(\%)$ \\
\hline Housing & 1 & 0 & 0 & 0 & $(*)$ \\
\hline Scholarships & 1 & 3 & 0 & 0 & $96.30 \%$ \\
\hline Environmental recommendations & 4 & 1 & 1 & 0 & $48.60 \%$ \\
\hline Cost & 7 & 5 & 1 & 1 & $41.60 \%$ \\
\hline Geographic distance & 2 & 0 & 1 & 1 & $(*)$ \\
\hline Country economy & 0 & 1 & 1 & 0 & $43.52 \%$ \\
\hline International experience & 0 & 3 & 3 & 0 & $99.50 \%$ \\
\hline Lack of positions & 1 & 0 & 0 & 0 & $20.40 \%$ \\
\hline Language & 3 & 4 & 3 & 1 & $87.50 \%$ \\
\hline Image and culture of the country & 5 & 4 & 2 & 0 & $93.50 \%$ \\
\hline Interest in emigrating & 2 & 0 & 0 & 0 & $23.61 \%$ \\
\hline Academic level of the center & 11 & 6 & 3 & 1 & $85.60 \%$ \\
\hline Academic level of the country & 3 & 2 & 1 & 0 & $77.30 \%$ \\
\hline Prestige and prospects & 8 & 6 & 3 & 1 & $90.30 \%$ \\
\hline Selection process & 4 & 0 & 0 & 0 & $(*)$ \\
\hline Safety & 6 & 2 & 1 & 0 & $(*)$ \\
\hline Visa & 1 & 0 & 0 & 0 & $28.20 \%$ \\
\hline Total of the studies & 12 & 8 & 3 & 1 & 24 \\
\hline
\end{tabular}

$\left.{ }^{*}\right)$ Not considered on the survey.

Table 16. Decision factors on different types of studies and the survey results

The comparison between the previous studies in the literature and the results of the survey shows us that the factors "Academic level of the center" and "Prestige and prospects" from having studied abroad coincide with one another. In fact, these factors are among the most significant in almost all the studies and they have also been highlighted by the survey respondents, which confirms the importance of these factors in the decision to study abroad. Furthermore, the rest of the factors that appear as most important in the survey results are specific to the flow of students analyzed and they characterize it. Specifically, they concern:

International experience. This factor was highlighted as important or critical by practically all of the survey respondents. This result coincides with that of three studies available on the motivations of Brazilian students to study abroad, thus indicating a particular characteristic of the motivations of students from this country. 
Scholarships. Scholarships have a very prominent importance among the students surveyed, as reflected by both the number of students receiving them and the responses to the survey in relation to the motivations. This circumstance is particular to the flow of Brazilian students to Spain in that this factor has a lesser presence in the studies in the literature pertaining to other flows.

Image and culture of the country and language. These two factors reflect the cultural proximity that exists between the two countries and their importance is not surprising, given that from this perspective, the proximity between Brazil and Spain is clearly superior to that which might exist between Brazil and other typical destinations in Europe or North America.

The results of this research make a contribution to the literature in that the flow of Brazilian students to Spain had not been previously analyzed. In spite of the specificity of this flow, its particular characteristics justified the development of a specific study, as the results have demonstrated. Indeed, the motivations of these students are not reflected by the factors identified in other studies referring to different flows.

This study forms part of the possible analyses of relationships that exist between universities in Brazil and Spain, which the authors consider to be of great interest and anticipate addressing in the future. Another possible line of analysis would be the study of other flows, such as those of Brazilian students to third countries and also those of other countries to Spain, in which characteristics specific to each case are likely to be identified.

\subsection{Proposals for future study}

This study should be expanded to a more significant sample, but one limitation that has been demonstrated in studies of this nature is the difficulty of contacting this type of subjects. This makes it necessary for researchers to adopt different approach strategies. Due to the exploratory nature of the research, instead of providing definitive, conclusive answers, this study leaves several questions open, the responses to which require a more indepth analysis.

This study also failed to take into account factors related to the destination cities. However, it must be considered that in the mobility process associated with studying abroad, for some students, the choice of city can take precedence over the center of study or university of interest.

\section{Declaration of Conflicting Interests}

The authors declared no potential conflicts of interest with respect to the research, authorship, and/or publication of this article.

\section{Funding}

The authors received no financial support for the research, authorship, and/or publication of this article.

\section{References}

Abubakar, B., Shanka, T., \& Muuka, G.N. (2010). Tertiary education: An investigation of location selection criteria and preferences by international students - the case of two Australian universities. Journal of Marketing for Higher Education, 20, 49-68. https:// doi.org/10.1080/08841241003788052

Ahmad, A.B., \& Shah, M. (2018). International students choice to study in China: An exploratory study. Tertiary Education and Management, 24(4), 325-337. https://doi.org/10.1080/13583883.2018.1458247

Ahmad, A.B., Hassan, H.A., \& Al-Ahmedi, M.W.A. (2017). Motivations of government-sponsored Kurdish students for pursuing postgraduate studies abroad: An exploratory study. Journal of Studies in International Education, 21(2), 105-119. https://doi.org/10.1177/1028315316662982

Ahmad, S.Z., \& Hussain, M. (2017). The analytic hierarchy process of the decision-making factors of African students in obtaining higher education in the United Arab Emirates. Compare: A Journal of Comparative and International Education, 47(2), 163-176. https://doi.org/10.1080/03057925.2016.1171703 
Altbach, P.G. (1998). Comparative Higher Education: Knowledge, the University, and Development (p. 240). Hong Kong: Comparative Education Research Centre. The University of Hong Kong.

Binsardi, A., \& Ekwulugo, F. (2003). International marketing of British education: Research on the students' perception and the UK market penetration. Marketing Intelligence \& Planning, 21, 318-327. https://doi.org/10.1108/02634500310490265

Cao, C., Zhu, C., \& Meng, Q. (2016). A Survey of the Influencing Factors for International Academic Mobility of Chinese University Students. Higher Education Quarterly, 70, 200-220. https://doi.org/10.1111/hequ.12084

Chen, H.-L. (2008). Internationalization or international marketing? Two frameworks for understanding international students' choice of Canadian universities. Journal of Marketing for Higher Education, 18(1), 1-33. https://doi.org/10.1080/08841240802100113

Ciência Sem Fronteiras (2014). O programa. http://www.cienciasemfronteiras.gov.br (Consulted: April, 2017).

de Oliveira, A.L., \& de Freitas, M.E. (2016). Motivations for international academic mobility: The perspective of university students and professors. Educação em Revista, 32(3), 217-246. https://doi.org/10.1590/0102-4698148237

Foster, M. (2014). Student destination choices in higher education: Exploring attitudes of Brazilian students to study in the United Kingdom. Journal of Research in International Education, 13(2), 149-162. https://doi.org/10.1177/1475240914541024

Gatfield, T., \& Chen, C. (2006). Measuring student choice criteria using the theory of planned behaviour: The case of Taiwan, Australia, UK and USA. Journal of Marketing for Higher Education, 16, 77-95. https://doi.org/10.1300/J050v16n01_04

Higher Education Funding Council for England (2004). International student mobility, report by the Sussex Centre for Migration Research, University of Sussex, and the Centre for Applied Population Research, University of Dundee. Retrieved from: www.hefce.ac.uk/pubs/hefce/2004/04i 30/04 30.pdf

Iorio, J., \& Fonseca, M.L. (2018). Estudantes brasileiros no ensino superior português: construção do projeto migratório e intenções de mobilidade futura. Finisterra - Revista Portuguesa de Geografia, 109, 3-20. https://doi.org/10.18055/Finis14556

James-MacEachern, M., \& Yun, D. (2017). Exploring factors influencing international students' decision to choose a higher education institution: A comparison between Chinese and other students. International Journal of Educational Management, 31(3), 343-363.https://doi.org/10.1108/IJEM-11-2015-0158

Jianvittayakit, L., \& Dimanche, F. (2010). An investigation of travel motivation as a factor in international students' choice of a foreign university: A Thai case study. Proceedings of the 4th International Colloquium on Tourism \& Leisure 2010. Bangkok: In M. Neal and C. Jones (Eds.).

Joseph, M., \& Joseph, B. (2000). Indonesian students' perceptions of choice criteria in the selection of a tertiary institution: Strategic implications. International Journal of Educational Management, 14, 40-44. https://doi.org/10.1108/09513540010310396

Kingeski, L., \& Olivella Nadal, J. (2018). International academic mobility: the attraction factors of Brazilians students in Spain. Editorial Universitat Politècnica de València. https://doi.org/10.4995/HEAD18.2018.8213

Li, M., \& Bray, M. (2007). Cross-Border Flows of Students for Higher Education: Push-Pull Factors and Motivations of Mainland Chinese Students in Hong Kong and Macau. Higher Education, 53, 791-818. https://doi.org/10.1007/s10734-005-5423-3

Lima, M.C., \& Contel, F.B. (2011). Internacionalização da Educação Superior. Nações ativas, nações passivas e a geopolitica do conbecimento. São Paulo: Alameda.

Luchilo, L. (2006) Movilidad de estudiantes universitarios e internacionalización de la educación superior. Revista CTS, 7(3, Septiembre de 2006), 105-133.

Marchetto, A. (2005). Los flujos "migratórios" en el mundo. Consecuencias y expectativas. Congreso. Nacional sobre la Pastoral de la Movilidad Humana. Veracruz, México. 
Maringe, F., \& Carter, S. (2007). International students' motivations for studying in UK HE: Insights into the choice and decision making of African students. International Journal of Educational Management, 21, 459-475. https://doi.org/10.1108/09513540710780000

Mazzarol, T., \& Soutar, G.N. (2002). The "Push-Pull" Factors influencing international student selection of education destination. International Journal of Educational Management, 16(2), 82-90.

https://doi.org/10.1108/09513540210418403

Mukherjee, S., \& Chanda, R. (2012). Student Mobility from India to Selected European Countries - The Case of Germany and France. (October 28, 2012). IIM Bangalore Research Paper No. 378, Available at SSRN: https://doi.org/10.2139/ssrn.2179724

Olivella Nadal, J. (2016). España como destino de estudiantes universitarios internacionales: Datos y tendencias. (Spain as Destination of International University Students: Facts and Trends) (January 27, 2016). Available at SSRN: http://ssrn.com/abstract=2723368 (Consulted: May, 2017).

Padlee, S.F., Kamaruddin, A.R., \& Baharun, R. (2010). International students' choice behaviour for higher education at Malaysian private universities. International Journal of Marketing Studies, 2, 202-211. https://doi.org/10.5539/ijms.v2n2p202

Parra Sandoval, M.C. (2014). La Movilidad de Estudiantes de Posgrado de Venezuela y México a Canadá: Un Estudio Exploratorio. Revista Latinoamericana de Educación Comparada, 5(5), 93-105.

Pimpa, N. (2005). Marketing Australian universities to Thai students. Journal of Studies in International Education, 9 , 137-146. https://doi.org/10.1177/1028315305274857

Shanka, T., Quintal, V., \& Taylor, R. (2005). Factors influencing international students' choice of an education destination - A correspondence analysis. Journal of Marketing for Higher Education, 15, 31-46. https://doi.org/10.1300/J050v15n02_02

Teichler, U. (2007). The Flexible Professional in the Knowledge Society: New Demands on Higher Education. Project Supported by the VI Framework Programme of the EU (pp. 199-220). Maastricht: Maastricht University.

Trejo Peña A.P., \& Suárez Bequir S.S. (2018). Estudiantado mexicano de posgrado en España: Motivaciones y mecanismos impulsores detrás de la movilidad estudiantil. Périplos: Revista De Estudos Sobre Migrações, 2(1).

Retrived from: http://www.periodicos.unb.br/index.php/obmigra periplos/article/view/21225

UNESCO (2006). Compendio Mundial de la Educación 2006: Comparación Estadística de la Educación en el Mundo, Instituto de Estadísticas de la UNESCO - UIS, Montreal. www.uis.unesco.org

UNESCO (2014). Global Flow of Tertiary-Level Students. Retrieved from: http://www.uis.unesco.org/Education/Pages/international-student-flow-viz.aspx (Consulted: April, 2017)

UNESCO (2019). UNESCO data on international student mobility in tertiary education. Retrieved from: http://data.uis.unesco.org/index.aspx?quervid $=169$

Wang, Z. (2010). Self-globalisation - a new concept in the push and pull theory: A study on Chinese self-funded master students. Paper presented at the Conference on Education and Citizenship in a Globalising World, London.

Wilkins, S., Balakrishnan, M.S., \& Huisman, J. (2011). Student choice in higher education: Motivations for choosing to study at an international branch campus. Journal of Studies in International Education, 16(5), 413-443. https://doi.org/10.1177/1028315311429002

Yang, M. (2007). What attracts mainland Chinese students to Australian higher education. International Journal of Educational Management, 4(2), 1-12.

Intangible Capital, 2020 (www.intangiblecapital.org)

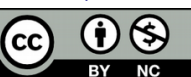

Article's contents are provided on an Attribution-Non Commercial 4.0 Creative commons International License. Readers are allowed to copy, distribute and communicate article's contents, provided the author's and Intangible Capital's names are included. It must not be used for commercial purposes. To see the complete license contents, please visit https://creativecommons.org/licenses/by-nc/4.0/. 